\title{
Corporate Social Responsibility (CSR) Practices in Coffee Producer Farmers' Cooperative Unions: The Case of Bench-Maji, Kaffa, and Sheka Zones, South Western Ethiopia
}

\author{
Mr. Tesfaye Megiso Begajo (MA) (Corresponding author) \\ Department of Cooperatives, Mizan-Tepi University \\ P.O Box 260, Mizan Aman, Ethiopia \\ Tel: 251-946-511-347Ｅ-mail:yenegetarobel604@gmail.com \\ Mr. Yidenek Woldesenbet Belina (MBA) \\ Department of Cooperatives, Mizan-Tepi University \\ P.O Box 260, Mizan Aman, Ethiopia
}

Tel: 251-913-909-023Ｅmail: yidenek2015@gmail.com

\author{
Mr. Gubay Aniley Getie (MBA) \\ Department of Management, Mizan-Tepi University \\ P.O Box 260, Mizan Aman, Ethiopia
}

Received: January 14, 2019

Accepted: May 1, 2019

Published: May 10, 2019

doi:10.5296/wjbm.v5i1.14224

URL: https://doi.org/10.5296/wjbm.v5i1.14224

\begin{abstract}
The seventh ICA principle of "concern for community" clearly urges the cooperatives to carry out sustainable community development activities. Even though the cooperatives are serving the community directly or indirectly, their sight to the concept Corporate Social Responsibility (CSR) is not clearly considered by their members, academicians, and the government. The objective of this study was to assess the corporate social responsibility practices performed by Coffee Producer Farmers' Cooperative Unions at the study area. In this study primary and secondary data source were used. The size of respondents was 395 members of Cooperative Society and 50 Government officials. The data was analyzed using
\end{abstract}




\section{Macrothink}

SPSS version 20. The finding shows that there are job creation, supply of agricultural input, and expansion of coffee processing industry for serving both members and non-members, whereas drawback on the awareness creation to the community, participation of community in planning, implementing, and evaluating community projects, inconsistent allocation of community fund, and financial statements at unions' offices for CSR budget. Therefore, management of the unions should participate the community during planning, implementing, and evaluating socially responsible projects, cooperative social responsibility practices should be thoroughly supervised and supported by the government, cooperatives from their annual surplus should allocate community fund, both GOs and NGOs working on sustainable development activity at the area must work with cooperatives, and Cooperatives have to maintain separate book of account to record financial activities of cooperative social responsibility practices.

Keywords: Corporate social responsibility, Community concern, Cooperative principle, Sustainable development, Cooperative management 


\section{Introduction}

\subsection{Background}

Cooperative enterprise is one of the business enterprises with its peculiar characteristics of solving its members' economic, social and cultural problems where individuals couldn't solve lonely. When the Co-operative enterprises are going to be established they start with the important service maximizing objectives rather than profit maximizing objective which bases the principles of ICA. Since it is organized in voluntary base and democratically controlled by members it must be always transparent to the members and the community around it. The seventh ICA principle of "concern for community" clearly urges the cooperatives to carry out sustainable community development program the so called Corporate Social Responsibility (CSR).

Claudia et al. (2012) the concern principle for the community of social cooperatives is being structured towards sustainable development of communities they belong to. Concern for the community is about corporate responsibility and refers to the fact that they promote other cooperative movements such as poverty prevention and environmental protection. According to Fentaye and Rao (2016) every business organization operates within a given society and the relationships that an enterprise has with the society in which it operates argued that business and society are interwoven rather than being distinct entities, and there is a natural fit between the idea of CSR and an organization's stakeholder. Corporate Social Responsibility (CSR) is a concept more and more common to organizations across the world. However, this concept has not been undertaken at a larger scale at universities of cooperative education, neither in research nor in teaching (Reinhard et al., 2010). Corporate Social Responsibility, as such, emerged in the late 1990's as a tool enabling companies not only to make them appear more social and environmental - friendly, but also to go beyond plain economic logic and to be fully aware of and integrated to social and environmental concerns facing the world. Many definitions of CSR describe it as a concept by which companies integrate those above mentioned concerns on a voluntary basis in their business behavior and in their interaction with stakeholders. To be socially responsible means going beyond legal compliance, which can even improve a company's competitiveness as investment in the social and environmental area, as well as in business practice, may have a direct influence on productivity (www.eurocoop.coop. accessed, October 10,2016, 8:30 AM).

Dr. Joshua (2013) Corporations around the world are struggling with a new role, which is to meet the needs of the present generation without compromising the ability of the next generations to meet their own needs. Organizations are being called upon to take responsibility for the ways their operations impact societies and the natural environment. They are also being asked to apply sustainability principles to the ways in which they conduct their business. CSR is a relatively new discipline and companies are more and more inclined to engage into producing a CSR report stating their best practices in a variety of activities. CSR assessment is a transparency tool for companies in a world where stakeholders are demanding more information (Broomhill, 2007). The revival of CSR is reflected also in its recent prominence in public debate (Lyon \& Maxwell, 2008). Kimberly (2002) Policy makers 
and community developers are increasingly interested in alternative models for local businesses that will be both responsive to community needs as well as stimulate local economic growth.

Recently, there has been a growing awareness that the responsibilities of businesses have become increasingly significant to contribute to the improvement of society, community and a country's economy. In order to be successful in today's competitive market, a company needs to create competitive advantage and differentiate itself from other companies. Cooperatives follow a unique business model which can be considered as truly socially responsible, with core principles such as concern for the Community and Democracy. According to the definition of the International Co-operative Alliance (ICA), the cooperative is "an autonomous association of persons united voluntarily together to meet their common economic, social, and cultural needs and aspirations through jointly-owned and democratically-controlled enterprise."

\subsection{Statement of the Problem}

The seventh ICA principle in cooperatives emphasizes the Concern for Community which implies the Cooperatives responsibility to work for the sustainable development of the communities around them through laws approved by their members. The old thinking was that if you make money you can do this positive social and environmental stuff but I think the true philosophy of sustainability is the interdependence. It's about mutual dependence or interdependence, rather than charity (Elizabeth et al., 2008). Claudia et al. (2012) stated that in 2007, at the 85th anniversary of International Day of Cooperatives, the message sent by the International Cooperative Alliance has approached the theme "Values and cooperative principles for social responsibility cooperative enterprise" in order to highlight the contribution that make the cooperator members as socially responsible citizens, working in the cooperatives around the world.

Karthikeyan (2013) comprehensive work on the social responsibility of Cooperatives through social statements approach is scarce. In fact, the need for studies on Cooperative social responsibility was felt only during recent years. As such lot of studies related to economic impact of Cooperatives was conducted and they paid scanty attention to social responsibility and impact of Cooperatives through social accounting and reporting by adopting social statement approach. Even though the cooperatives are serving the community directly or indirectly their sight to the concept CSR is not considered in clear scientific meaning both by the cooperatives, their members, academic institutions and the government. Since Cooperatives and their Stakeholders' have a little knowhow about social responsibility in its special mission in Ethiopia, this research will spark a light for them to know what Cooperative Social Responsibility is and how to incorporate in their strategic plan as social obligatory tool.

\subsection{Objective of the Study}

The general objective of the study was to assess the practices performed by Coffee producer Farmers' Cooperative Unions regarding Corporate Social Responsibility for Community 
Development at the study area. Specifically focused to:

$>$ Identify the application of social projects by the unions that enhances sustainable development for the community;

$>$ Identify the corporate social responsibility practices performed by the unions based on reports and financial statements; and

$>$ Identify the attention given to concern for community principle based on Ethiopian cooperative laws in compliance with the ICA principle in supporting corporate social responsibility practices.

\section{Literature Review}

\subsection{Historical Development of Corporate Social Responsibility (CSR) in the World}

Financial Times (http://lexicon.ft.com/.Accessed 2016) corporate social responsibility (CSR) is a business approach that contributes to sustainable development by delivering economic, social and environmental benefits for all stakeholders. CSR is a concept with many definitions and practices. The way it is understood and implemented differs greatly for each company and country. Moreover, CSR is a very broad concept that addresses many and various topics such as human rights, corporate governance, health and safety, environmental effects, working conditions and contribution to economic development. Whatever the definition is, the purpose of CSR is to drive change towards sustainability. Although some companies may achieve remarkable efforts with unique CSR initiatives, it is difficult to be on the forefront on all aspects of CSR.

Mallen Baker's Respectful Business Blog (2004) cited the World Business Council for Sustainable Development in its publication 'Making Good Business Sense' by Lord Holme and Richard Watts, definition as follows: Corporate Social Responsibility is the continuing commitment by business to behave ethically and contribute to economic development while improving the quality of life of the workforce and their families as well as of the local community and society at large. The Blogger continued the definition of CSR from different bodies in the following manner. Definitions as different as CSR is about capacity building for sustainable livelihoods, it respects cultural differences and finds the business opportunities in building the skills of employees, the community and the government from Ghana, through to CSR is about business giving back to society from the Philippines, in the United States, CSR has been defined much more in terms of a philanthropic model whereas the European model is much more focused on operating the core business in a socially responsible way, complemented by investment in communities for solid business case reasons. Karin et al., (2010) stated a widely used definition comes from the research of Westebbe and Logan (1995) who define corporate citizenship as the holistic, coordinated and strategically aligned engagement of a company beyond its usual business goals to help resolve social issues. www.eurocoop.coop (Accessed 2008) Corporate Social Responsibility is the new "religion" in business. Broomhill, (2007) Corporate Social Responsibility (CSR), a concept that has been around for well over 50 years, has become prominent again recently. Claudia et al. (2012) nowadays, social responsibility becomes an important tool in economic activity of a company, 
a tool useful for the community and the industries. In this way, it is possible to get to collaboration between the company and the society in which both take care of community prosperity where they work and exist, helping each other to remove poverty, concerns for the stakeholders and the environment.

\subsection{Historical Development of Corporate Social Responsibility in Ethiopia}

There were studies on Corporate Social Responsibility issues in Ethiopia like Corporate Social Responsibility in Sustainable Environment Management in Ethiopia (Asemamaw \& Tilahun, 2011). CSR is about how companies manage the business processes to produce an overall positive impact on society (Mellan, 2015, p. 1).

The Cooperative Proclamation No. 147/1998 identified clear goals and authorities, which supported a more conducive legal environment for the formation of Ethiopian cooperatives. Co-operative societies work for the sustainable development of their communities through policies approved by their members (Proclamation No 147/1998, Article 5; 7). However, the extent to which the cooperatives in Ethiopia have been able to attain these goals has not been adequately analyzed (Bezabih, 2009). Aminul et al. (2014) cited in the ICA, 1995 explanation as Cooperation is an industry where fine rational human beings are produced with the materials of honesty, unity, equality, etc. Karthikeyan (2013) Cooperatives strive to create a higher social order and cooperative common wealth.

\subsection{Approaches of Corporate Social Responsibility of Business Enterprises}

Alessia D'Amato et al. (2009) Corporations around the world are struggling with a new role, which is to meet the needs of the present generation without compromising the ability of the next generations to meet their own needs. They are also being asked to apply sustainability principles to the ways in which they conduct their business. Ray Broomhill (2007, pp. 6-9) cited Jeremy Moon (2004) idea as, CSR is a difficult concept to pin down. It overlaps with other such concepts as corporate citizenship, sustainable business, environmental responsibility, the triple bottom line; social and environmental accountability; business ethics and corporate accountability. However he further discussed the concept in three different schools approaches viz. the neoliberal, neo-Keynesian, and radical political economy approaches. In defining CSR, neoliberal writers tend to see it fundamentally as the adoption of a set of voluntary policies, codes or guidelines, initiated and driven by the corporation. However, even here, the neoliberal assumption is that CSR is a minor component of corporate strategy at best. Neo-Keynesian approaches tend to utilize a wider definition that more clearly recognizes the active role of the corporation's 'stakeholders', and perhaps also the state, in the definition of what is corporate social responsibility. Again, however, CSR is generally defined as an approach adopted voluntarily by corporations and without external regulation by either stakeholders or the state. Radical political economy approaches take a far more critical stance around CSR on several issues. All 'schools' of thought in these debates of course possess normative views about the role of business in general and corporations in particular in society.

Advocates of voluntary CSR are perceived as lacking a critical political economy analysis and therefore fail to fully understand and incorporate a realistic view of the power structures 
that exist in society and its economic environment. Hence many of the policies and practices that have been developed to promote CSR are viewed as naïve, ineffectual and inadequate. Many activist groups, and others who adopt a radical critique of CSR approaches, openly reject voluntary CSR and advocate an alternative strategy that is generally described as 'corporate accountability'.

\subsection{Corporate Social Responsibility of Cooperative Enterprises}

Aminul and Mohammad (2014) explained that the cooperative becomes a socially responsible industry when it appears because, by respecting its principles, it promotes democracy, mutual help and social integration of its members; also through its work it influences a large number of people. At the same time, cooperative societies are enterprises that include in their economic activity, duties that are not profitable for other enterprises but are necessary for the population. In general, cooperatives are not only interested in maximizing profits but also promote its social mission. The cooperative is an association of people not of capital. Aminul and Mohammad (2014) again stated as "The main advantage of cooperative enterprises over other enterprises is that they are located close to the communities where they activate, some of them being situated far away from the economic centers of the country, in this way, those places are better informed about the needs and the problems of the community. Another advantage of cooperatives for social responsibility is the fact that the cooperative members are often the same people living in that community, in this way, by helping those members, it will lead to the economic development of the locality. This means that a cooperative company becomes socially responsible along with its foundation." One advantage for the concept of social responsibility itself would be the fact that it is based on informing and educating members of the cooperative which would lead to knowing them better and informing the population about the meaning and importance of social responsibility.

The Co-operative Group Sustainability Report (2013) Co-operative members believe in the ethical values of honesty, openness, social responsibility and caring for others. The cooperatives, as democratic structures, have always had goals beyond the initial financial results. The cooperative values and principles have been underlying operational model of cooperative business for over 150 years. Claudia et al. (2012) the cooperative is an economic organization formed by the free consent association of a group of people which brings together the means of production and labor for the production, purchase, disposal jointly of some goods, loans, provision of services. Values are basic ones for the assumption of the corporative social responsibility.

The Co-operative Group Sustainability Report (2013) in order to enhance the corporate social responsibility some cooperatives undertake the fund rising from the members profit dividend. For instance the Cooperative Group of UK, the Community Fund14 supports voluntary and self-help community organizations by awarding small grants of between $£ 100$ and $£ 2,000$ This group also undertakes the social responsibility activities for youth development. Sydney Credit Union's (2007) the phrase Corporate Social Responsibility is changed as Cooperative Social Responsibility in case of Cooperative enterprises based on their basic principles and 
values. The Sydney Credit Union practically uses this term even formulating its own model. Cooperatives as business enterprises also have to work in line with this new emerging idea, even though it is not now for them because Cooperatives are primarily familiar with their principle of concerning for the community.

\subsection{Empirical Study}

Ray Broomhill (2007, pp. 9-11) discussed referencing different scholars argument such as Rhys Jenkins argues that, while the current wave of interest in corporate social responsibility (CSR) dates from the early 1990s, it is only a new manifestation of 'a longstanding debate over the relationship between business and society' (Jenkins, 2005, p. 526). Since the rise of the corporation in the late nineteenth century, this debate has continued, through periods 'when the power of corporations is in the ascendancy and periods in which society attempts to regulate the growth of corporate power' (Ibid). In these periods when corporations have become subject to public criticism and attempts at regulation, they have attempted to re-establish their legitimacy by adopting CSR style strategies. In the late 19th century the emergence of large corporations and the era of the robber barons in the US led to the development of the anti-trust movement. In response, corporations emphasized corporate responsibility and philanthropy in order to prove that government regulation was unnecessary (Richter, 2001).

During the 1990s, awareness of the use of sweatshops and child labor in developing countries attracted the attention of community activists in developed societies. The 1990s therefore witnessed an explosion in civil group activism which led to both protests against and engagement with, corporations (Bendell, 2004). The demand for greater social responsibility came from a wide range of sources including international trade unions, development NGOs, human rights organizations and environmental groups. Corporations were again forced to respond to bad publicity surrounding their activities. Corporate social responsibility discourse and programs emerged in part as a direct response to these pressures. According to Rajasekhara and Zelalem (2008), Ethiopian companies expressed 100 percent positive attitude in implementing CSR towards customers, creditors and suppliers, general public and government. However, only 40 percent of companies' were positive on periodical disclosure of information to its shareholders. 71 percent customers thought they were manipulated and another 75 percent general public was not pleased with CSR from the Ethiopian corporate sector.

\subsection{Analytical Framework}

Mellan (2015, p. 1) Companies need to answer to two aspects of their operations regarding CSR. First, the quality of their management - both in terms of people and processes and the next one is the nature of, and quantity of their impact on society in the various areas. Outside stakeholders are taking an increasing interest in the activity of the company. Most look to the outer circle - what the company has actually done, good or bad, in terms of its products and services, in terms of its impact on the environment and on local communities, or in how it treats and develops its workforce. Out of the various stakeholders, it is financial analysts who are predominantly focused - as well as past financial performance - on quality of management 
as an indicator of likely future performance. International Institute for Labour Studies (2008) stated that if enterprise is to be sustainable, legal and accounting techniques which enable CSR practices need to be implemented. The business case built in this domain is focused on exploiting CSR activities in order to build value through gains in firm reputation and legitimacy. Socially responsible investing focus on value creation by leveraging gains in reputation and legitimacy made through aligning stakeholder interests (Elizabeth et al., 2008).

Seven cooperative principles and CSR (http://www.cdi.coop/icaprinciples.html, accessed 6/8/2016, 1:22AM) implies voluntary nature of SR, credibility and transparency of CSR practices, attention to the specific needs of Society, balance and all-encompassing approach to CSR, including economic, social and environmental issues as well as consumer interests, focus on activities where Community involvement adds value, support and compatibility with existing international agreements and instruments. Stakeholders for the study are: members, management committee members and employees of the union. Members' Perception on the social performance of the Union, Management Committee's Perception on the social performance of the Union, and Employees' Perception on the social performance of the Union has been discussed (Karthikeyan, 2013). The attributes of board members are foresight and extensive knowledge, criticality, independent judgment and autonomy, cooperative, diligence and time-effective and specialized know-how in some part area (Adeyemi, 2014).

There are so many indicators to evaluate the practices of Cooperative Social Responsibility performance of the Coffee Marketing Cooperative Unions in study area based on the review. These are unions management attention to corporate social responsibility, allocation of community concerned fund, and expansion of social service projects. These three factors are independent variables that are important to evaluate the performance of corporate social responsibility Practices of Cooperative unions.

3. Expansion of Community Concerned projects

* Expansion of coffee collection units nearest to farmers,

* Forest development,

* Employment opportunity

* Road construction

* Building of schools, health centers, water supply.

1. Unions Management Attention to Corporate Social Responsibility

* Reporting to General Assembly meeting on CSR Practices

* Decisions passed on annual plan and report by GA

* Arrangement of Communities forums to evaluate CSR practices
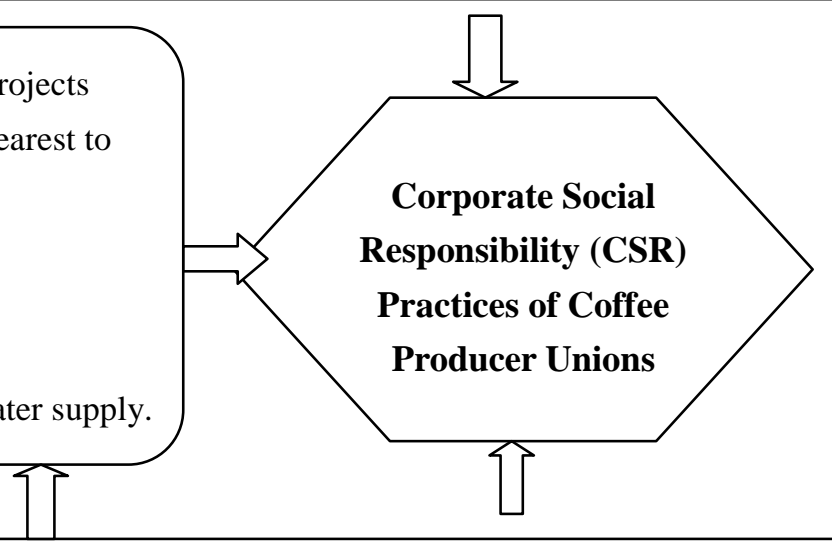

2. Allocation of Community Concerned Fund from Unions annual earning

Figure 1. Conceptual framework

Source: Researchers own Framework based on Review of Related Literature. 


\section{Research Methodology}

This chapter highlights the approach and methodology adopted for undertaking the study including coverage, sampling plan and instruments used.

\subsection{Description of the Study Area}

The SNNPR borders Kenya to the south, South Sudan to the west, Gambela region to the northwest, and Oromia region to the north and east. The SNNPR, being an amalgam of the main homelands of numerous ethnicities, contains over 65 indigenous ethnic groups. The region contains 15 Zones including Hawassa Town Administration and 4 special woredas. Bench-Maji, Kafa and Sheka zones are one of 15 zones found Southwest Ethiopia of the region with their abundant natural forest and gifts of economic resources like coffee, Haney and different spices. Based on the 2007 Census conducted by the Central Statistical Agency of Ethiopia (CSA), the SNNPR has an estimated total population of $14,929,548$, of whom $7,425,918$ were men and 7,503,630 women. $13,433,991$ or $89.98 \%$ of the population are estimated to be rural inhabitants, while $1,495,557$ or $10.02 \%$ are urban; this makes the SNNPR Ethiopia's most rural region. With an estimated area of 105,887.18 square kilometers, this region has an estimated density of 141 people per square kilometer. For the entire region $3,110,995$ households were counted, which results in an average for the Region of 4.8 persons to a household, with urban households having on average 3.9 and rural households 4.9 people.

\subsubsection{Overview of Study Areas}

Bench Maji is one of 15 Zones find at South Nations, Nationalities, and Peoples' Regional State (SNNPRS) of South west Ethiopia at a distance of $561 \mathrm{~km}$ from Addis Abeba. It is bordered at the west by South Sudan, on the northwest with Gambela Region, on the north with Sheka zone, at northeast with Keffa zone, and at the east by South Omo Zones. The Omo River defines much of its eastern border with South Omo. The administrative center of Bench Maji is Mizan-Aman. The agro-Ecology of the Bench Maji zone is that out of the total land size $28.042 \%$ is kolla, $15.44 \%$ weinadega and $56.74 \%$ dega. The annual mean temperature ranges between $15.1-27^{\circ} \mathrm{C}$ and the annual mean rain fall ranges $400-2000 \mathrm{~mm}$. The Central Statistical Agency (CSA, 2007) reported that 10,097 tons of coffee was produced in Bench Maji in the year ending in 2005, based on inspection records from the Ethiopian Coffee and Tea authority. This represents $10.6 \%$ of the SNNPR's output and $4.4 \%$ of Ethiopia's total output. Based on the 2007 Census conducted by the CSA, this Zone has a total population of 652,531 , of whom 323,348 are men and 329,183 women. Based on regional average number of 4.8 people per house hold, this zone has 135,943 house hold.

Keffa is bordered on the south with Debub Omo, on the southwest with Bench Maji, on the west with Sheka, on the north with the Oromia Region, and on the east by Konta special woreda. Based on the 2007 Census conducted by the CSA, this Zone has a total population of 874,716 , of whom 431,778 are men and 442,938 women; out of the total population 809,680 $(92.56 \%)$ are living in rural area and 65,036 or $7.44 \%$ are urban inhabitants. Sheka zone is bordered on the south with Bench Maji, on the west with Gambela Region, on the north with Oromia Region, and on the east with Keffa. Based on regional average growth number of 4.8 


\section{Macrothink}

World Journal of Business and Management

ISSN 2377-4622

2019, Vol. 5, No. 1

people per house hold, this zone has 182,233 house hold. The administrative center of Sheka is Masha. Based on the 2007 Census conducted by the CSA, this Zone has a total population of 199,314 , of whom 101,059 are men and 98,255 women; 34,227 or $17.17 \%$ are urban inhabitants. Based on regional average number of 4.8 people per house hold, this zone has 41,524 house hold.

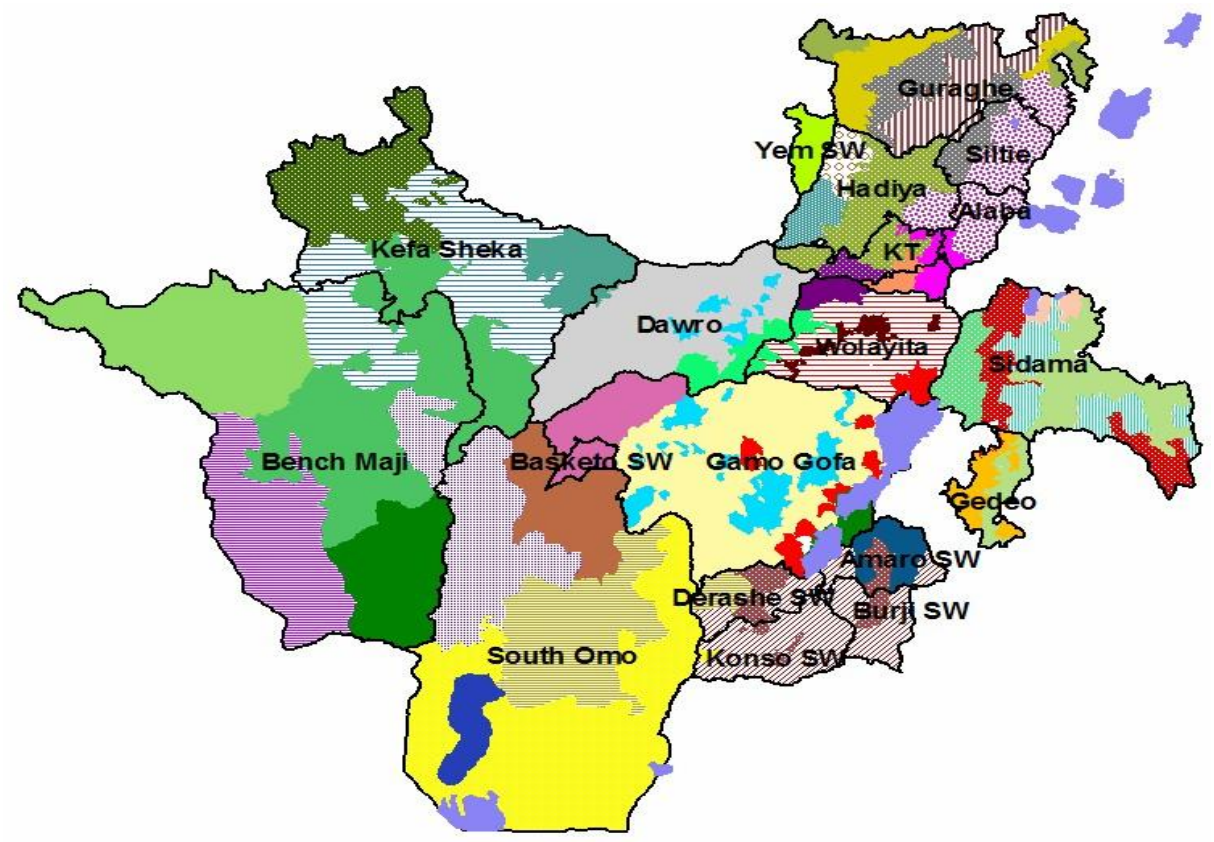

Figure 2. Map of the research area

Source: SNNPRS, Bureau of Culture and Tourism, 2009.

\subsubsection{An Overview of Cooperatives in the Study Area}

Bench Maji Forest Coffee Producer Farmers' Cooperative Union was established in July 2005 G.C by 14 founder member primary cooperatives (PCs) to operate in Bench Maji Zone to engage in the marketing of coffee product on behalf of its members and provide inputs and other household \& production necessities. The number of individual members of the founder PCs was 4,968 with 3808 males and 1160 female. Currently, the union has 46 member primary cooperatives, 10,011 individual members of which 8294 males and 1717 female. The union was established to make its members benefit fully from their coffee marketing engaged in the domestic and mainly international markets. The Union's members also produce other forest Products such as honey and spices in addition to coffee; and it also has started working on Spices such as Cardamom, Turmeric, Ginger, Black Pepper, Long pepper, and other spices. The PCs are distributed in six Woredas of Bench Maji Zone, which are endowed with high production and marketable potential of coffee, Spice and honey. Major marketing businesses include washed and natural dry coffee processing, testing, marketing and exporting. Local businesses include spices, sesame, honey and grain marketing; and consumer goods and factory products supply and input distribution to members and non-members

The Kafa Coffee Producer Farmers' Cooperative Union is known for supplying the finest 
Ethiopian Arabica coffee. The coffee Farm coverage of Kafa Zone is 220,350 hector and it has potential of producing 9000 tons of forest coffee. In Kaffa zone there are 43 forest coffee producers' primary cooperatives which are the members of the Kafa Forest Coffee Farmers' Cooperative Union. This union was established December 2004 E.C encompassing 17 primary Cooperatives with individual members of 4267 among this 3990 are male and 277 are females. Currently the member societies are increased to 43 and individual members became 10,718 of this 8154 are males and 2564 are females. The union has 15,060,747 birr capital and until now the union has earned surplus of birr 18,116,940.19 for. Tepi Coffee Producer Farmers' Cooperative Union found at Sheka zone where there are 19 member primary cooperatives. The union has 1050 total members. Know days the member cooperatives are 21 having 1673 individual members with 1347 male and 326 female.

\subsection{Research Approach}

Considering the fact that Cooperative Social Responsibility as a process is connected to the Development Process, which is holistic in nature. The approach adopted for study of Cooperative Social Responsibility performance has been holistic one with a focus on the participation of various stakeholders in the Development system involving, direct beneficiaries (Members), Cooperative Leaders, and Government Officials at different levels (Kebel, Woreda, and Zone). The researchers employed survey type of research approach giving emphasis on both quantitative and qualitative research method.

\subsubsection{Source of Data}

For this study both primary and secondary data were used. The primary data was collected from cooperative Unions BODs, Managers, Employees, Cooperative members, and government officials using questionnaires and interviews. In addition for conducting the study, secondary data was gathered from unions' financial statements and management reports.

\subsubsection{Methods of Data Collections}

Survey study was conducted to gain an insight into the state of Cooperative social responsibility. Additionally, extensive secondary data from available literatures and Cooperatives document were undertaken to collect and assimilate secondary information / data on the subject of Corporate Social Responsibility of Cooperative Unions. So as to study the social projects undertaken by the Unions and the satisfaction level of the stakeholders regarding social responsibility practices of the Unions questionnaires consisting of close-ended and open-ended were prepared for the sample respondents.

\subsubsection{Sample Size Determination and Sampling Techniques}

The study conducted in three zones and three Coffee Producing Farmers' Cooperative Unions. The researchers employed purposive sampling techniques for selecting interviewee groups of Woreda and Zone government officials based on their position nearer to the topic. The total number of members in three unions there are 22,402 members. Therefore, to determine the sample of the respondent, Yamane's (1967), formula was applied. 


$$
\begin{gathered}
n=\frac{N}{1+N(e)^{2}}, \\
n=\frac{32,099}{1+32,099(0.05)^{2}}=\frac{32,099}{81.2475}=395.1
\end{gathered}
$$

Where: $\mathrm{n}=$ number of sample size

$\mathrm{N}=$ number of total population

$e=$ level of confidence is $95 \%$ for this study.

Therefore 395 samples member were determined as sample, Additionally 50 government officials including Cooperative office employees (Woreda, and Zone) were selected as key informants. The determined sample size was allocated to each union by dividing to the total population.

Table 2. Sample respondents for questionnaires

\begin{tabular}{|c|c|c|c|c|c|}
\hline \multicolumn{2}{|c|}{ Name of Unions } & \multicolumn{5}{|c|}{ Total individual sample Size } \\
\cline { 2 - 6 } & $\begin{array}{c}\text { Member } \\
\text { Population }\end{array}$ & Ratio & $\begin{array}{c}\text { Sample } \\
\text { Members }\end{array}$ & $\begin{array}{c}\text { Government } \\
\text { Officials }\end{array}$ & Total \\
\hline $\begin{array}{l}\text { Bench-Maji Forest Coffee } \\
\text { Farmers' Cooperative Union }\end{array}$ & 10,011 & & & 20 & 145 \\
\hline $\begin{array}{l}\text { Kafa Forest Coffee Producers } \\
\text { Cooperative Union }\end{array}$ & 10,718 & 0.312 & 123 & 20 & 152 \\
\hline $\begin{array}{l}\text { Tepi Coffee Producing Farmers' } \\
\text { Cooperative Union }\end{array}$ & 11,370 & 0.334 & 132 & 10 & 150 \\
\hline \multicolumn{1}{|c|}{ Total } & $\mathbf{3 2 , 0 9 9}$ & $\mathbf{1}$ & $\mathbf{3 9 5}$ & $\mathbf{5 0}$ & $\mathbf{4 4 7}$ \\
\hline
\end{tabular}

Source: Each Zones Cooperative Office Annual Report, 2009 E.C.

\subsubsection{Data Analysis}

Following the completion of collecting the data, it was edited, coded and entered into MS Excel and analyzed using Statistical Package for Social Science (SPSS version 20) computer program for draw out descriptive results in the form frequency and percentage. Finally, the qualitative data were analyzed in the form of discussion by evaluating the content from the response of open-ended questions as well as unions' reports.

\section{Result and Discussion}

\subsection{Demographic Characteristics of the Respondents}

In this part the demographic characteristics of the respondents such as age, gender, marital status, family size, occupation, educational level, and position in the Cooperative society has been discussed. 
Table 3. Sex, age, and occupation of respondents

\begin{tabular}{|l|l|c|c|}
\hline Description & Frequency & Percent (\%) \\
\hline \multirow{3}{*}{ Sex } & Male & 289 & 74 \\
\cline { 2 - 4 } & Female & 100 & 26 \\
\cline { 2 - 4 } & Total & $\mathbf{3 8 9}$ & $\mathbf{1 0 0}$ \\
\hline Age & $=<20$ year & 21 & 5.4 \\
\hline & 21-30 year & 98 & 25.2 \\
\hline & 31-40 year & 124 & 31.9 \\
\hline & 41-50 year & 104 & 26.7 \\
\hline & $>50$ year & 42 & 10.8 \\
\hline & Total & $\mathbf{3 8 9}$ & $\mathbf{1 0 0 . 0}$ \\
\hline Occupation & Farmer & 293 & 75.3 \\
\hline & Petty Trade & 66 & 17.0 \\
\hline & Handcrafts Man & 9 & 2.3 \\
\hline & Employee & $\mathbf{3 8 9}$ & 5.4 \\
\hline & Total & $\mathbf{1 0 0 . 0}$ \\
\hline
\end{tabular}

Source: Researchers field survey, 2018.

Above it shows out of 389 respondents 289(74\%) are male and 100(26\%) females. Concerning the age 21(5.4\%) are below 20 years, 98(25.2\%) between 21-30 years, $124(31.9 \%)$ are $31-40$ years, $104(26.7 \%)$ are in between $41-50$ years, and $42(10.8 \%)$ are above 50 years. Regarding their occupation out of 389 respondents $293(75.3 \%)$ are farmers, 66(17\%) are petty traders, 9(2.3\%) are handcrafts man, and 21(5.4\%) are Employees in different institutions at study area.

Table 4. Marital status, educational level, and family size

\begin{tabular}{|l|l|c|c|}
\hline Description & Frequency & Percent \\
\hline \multirow{5}{*}{ Marital Status } & Married & 283 & 72.8 \\
\cline { 2 - 4 } & Single & 67 & 17.2 \\
\cline { 2 - 4 } & Divorced & 18 & 4.6 \\
\cline { 2 - 4 } & Widowed & 21 & 5.4 \\
\cline { 2 - 4 } & Total & $\mathbf{3 8 9}$ & $\mathbf{1 0 0 . 0}$ \\
\hline Educational Level & Illiterate & 112 & 28.8 \\
\cline { 2 - 4 } & $1-8^{\text {th }}$ & 186 & 47.8 \\
\cline { 2 - 4 } & $9-12^{\text {th }}$ & 67 & 17.2 \\
\cline { 2 - 4 } & Level I-III & 15 & 3.9 \\
\cline { 2 - 4 } & Diploma and Above & 9 & 2.3 \\
\cline { 2 - 4 } & Total & $\mathbf{3 8 9}$ & $\mathbf{1 0 0 . 0}$ \\
\hline Family Size & $<=5$ member & 229 & 58.9 \\
\cline { 2 - 4 } & 6-8 members & 120 & 30.8 \\
\cline { 2 - 4 } & $9-10$ members & 9 & 2.3 \\
\cline { 2 - 4 } & Above 10 & & \\
\hline
\end{tabular}

Source: Researchers field survey, 2018. 


\section{Al Macrothink}

World Journal of Business and Management

ISSN 2377-4622

2019, Vol. 5, No. 1

When looking the marital status of respondents, majority (283 or $72.8 \%$ ) are married, $67(17.2 \%)$ are single, 18(4.6\%) are divorced, and $21(5.4 \%)$ are widowed. The educational level of respondents is $112(28.8 \%)$ are illiterate, $186(47.8 \%)$ are $1-8^{\text {th }}$ grade, $67(17.2 \%)$ are $9-12^{\text {th }}$ grade, $15(3.9 \%)$ are from Level I-III, and 9(2.3\%) are diploma and above. The family size of the member respondents is shown at the above table as $229(58.9 \%)$ have up to 5 family members, $120(30.8 \%)$ have $6-8$ family members, $31(8.0 \%)$ have $9-10$ family members, and $9(2.3 \%)$ have more than 10 family members

Table 5. Membership and position in their cooperative

\begin{tabular}{|l|l|c|c|}
\hline Description & Frequency & Percent \\
\hline Membership in year & $<=1$ year & 106 & 27.2 \\
\cline { 2 - 4 } & 2-5 years & 91 & 23.4 \\
\cline { 2 - 4 } & $>=6$ years & 192 & 49.4 \\
\cline { 2 - 4 } & Total & $\mathbf{3 8 9}$ & $\mathbf{1 0 0 . 0}$ \\
\hline Position & Member & 326 & 83.8 \\
\cline { 2 - 4 } & Committee Member & 40 & 10.3 \\
\cline { 2 - 4 } & Consultants (Cooperative Promoters) & 11 & 2.8 \\
\cline { 2 - 4 } & Accountant & 12 & 3.1 \\
\cline { 2 - 4 } & Total & $\mathbf{3 8 9}$ & $\mathbf{1 0 0 . 0}$ \\
\hline
\end{tabular}

Source: Researchers field survey, 2018.

According to the above table out of 389 respondents 106(27.2\%) are being member for 1 year and below, 91(23.4\%) are for 2-5 years, and 192(49.4\%) are 6 years and above. Regarding position of the respondent in their cooperatives, $326(83.8 \%)$ are members only, 40(10.3\%) are committee members at different level, 11(2.8\%) are consultant of cooperatives (kCPA), and $12(3.1 \%)$ are accountants.

\subsection{The Corporate Social Responsibility Practices Preformed by Cooperatives}

There were three independent variables applied to evaluate the performance of corporate social responsibility practices of Cooperatives in this study. These are unions management attention to corporate social responsibility, allocation of community concerned fund, and expansion of social service projects.

\subsubsection{Unions Management Attention to Corporate Social Responsibility}

Unions Management Attention to Corporate Social Responsibility encompasses three issues in this study such as reporting to general assembly meeting about CSR practices performed to the community, decisions passed on annual plan and report by general assembly, and arrangement of communities' forums to evaluate CSR practices by cooperatives. 


\section{Macrothink}

World Journal of Business and Management

ISSN 2377-4622

2019, Vol. 5, No. 1

Table 6. Management attention given to CSR practices

\begin{tabular}{|l|c|c|c|c|c|c|}
\hline \multirow{2}{*}{ Description } & \multicolumn{5}{c|}{ Response } \\
\cline { 2 - 7 } & \multicolumn{2}{|c|}{ Yes } & \multicolumn{2}{c|}{ No } & \multicolumn{2}{c|}{ Total } \\
\cline { 2 - 8 } & Freq. & \% & Freq. & \% & Frer. & \% \\
\hline $\begin{array}{l}\text { Does the Union Management Report CSR } \\
\text { activities to General assembly as a separate } \\
\text { agenda? }\end{array}$ & & & & & & \\
\hline $\begin{array}{l}\text { Is there Participation of Community members on } \\
\text { CSR Performance Evaluation? }\end{array}$ & 93 & 23.9 & 296 & 76.1 & 389 & 100 \\
\hline $\begin{array}{l}\text { Does the Community have awareness on the } \\
\text { Operation Undertaken by Union on CSR Activity }\end{array}$ & 184 & 47.3 & 205 & 52.7 & 389 & 100 \\
\hline
\end{tabular}

Source: Researchers field survey, 2018.

In the above table 6 out of 389 respondents 93(23.9\%) responded that management body reports the performance of CSR activities to the general assembly at their annual report, whereas 296(76.1\%) replied no. Regarding participating Community members on corporate social responsibility performance evaluation of cooperatives was responded as $63(16.2 \%)$ replied yes and the remaining 326(83.8\%) said no. Additionally out of 389 respondents $184(47.3 \%)$ replied that the community has awareness on the operation of unions on CSR activities and the rest 205(52.7\%) said no awareness.

\subsubsection{Allocation of Community Concerned Fund}

In order to undertake CSR activities Cooperative Unions must plan and allocate fund which is approved by their annual general assembly meeting. If management gives attention for community concerned principle they will plan work and prepare budget to be approve by general assembly. Based on this view point both primary data from the respondents and secondary data from unions financial and performance report were collected.

Table 7. Allocated funds for CSR practices by the Unions

\begin{tabular}{|l|c|c|c|c|c|}
\hline \multicolumn{1}{|c|}{ Cooperative Unions } & $\mathbf{2 0 1 2}$ & $\mathbf{2 0 1 3}$ & $\mathbf{2 0 1 4}$ & $\mathbf{2 0 1 5}$ & Total \\
\hline BMCPFCU & & & & & \\
\hline Pure water supply & - & - & - & - & 0 \\
\hline School building & - & - & - & 30,000 & 30,000 \\
\hline Road construction & - & - & - & 50,000 & 50,000 \\
\hline Forest development & --- & --- & --- & 250,000 & 250,000 \\
\hline Other & - & --- & --- & 152,500 & 152,500 \\
\hline Total & & & & $\mathbf{4 8 2 , 5 0 0}$ & $\mathbf{4 8 2 , 5 0 0}$ \\
\hline KFCFCU & & & & & \\
\hline Pure water supply & - & $243,484.85$ & - & - & $243,484.85$ \\
\hline School building & - & - & - & $217,287.66$ & $217,287.66$ \\
\hline
\end{tabular}




\begin{tabular}{|l|c|c|c|c|c|}
\hline Road construction & - & - & - & - & 0.00 \\
\hline Forest development & $736,452.96$ & $637,547.76$ & $649,660.44$ & $824,766.37$ & $2,848,427.53$ \\
\hline Reproductive Health care) & 309,715 & 329,681 & 394,891 & 399,656 & $1,433,943.00$ \\
\hline Total & $\mathbf{1 , 0 4 6 , 1 6 7 . 9 6}$ & $\mathbf{1 , 2 1 0 , 7 1 3 . 6 1}$ & $\mathbf{1 , 0 4 4 , 5 5 1 . 4 4}$ & $\mathbf{1 , 4 4 1 , 7 1 0 . 0 3}$ & $\mathbf{4 , 7 4 3 , 1 4 3 . 0 4}$ \\
\hline TCFCU & & & & & \\
\hline Forest development & 0 & 75,345 & 42,500 & 0 & $\mathbf{1 1 7 , 8 4 5}$ \\
\hline
\end{tabular}

Source: Unions Annual Report, 2008 E.C.

According to the above table three unions found in Bench Maji, Kafa, Sheka Zones are working for sustainable community development, however there is significant difference among them. The report from Kafa union shows that they are working in collaboration with various international partners getting funds for the above community concerned projects.

Table 8 . Created job opportunity by the Unions

\begin{tabular}{|c|c|c|c|c|c|c|c|c|c|c|c|c|c|c|c|}
\hline \multirow[t]{2}{*}{ Unions } & \multicolumn{3}{|c|}{2012} & \multicolumn{3}{|c|}{2013} & \multicolumn{3}{|c|}{2014} & \multicolumn{3}{|c|}{2015} & \multicolumn{3}{|c|}{ Cost Expended in Birr } \\
\hline & $\mathbf{M}$ & $\mathbf{F}$ & $\mathbf{T}$ & $\mathbf{M}$ & $\mathbf{F}$ & $\mathbf{T}$ & $\mathbf{M}$ & $\mathbf{F}$ & $\mathbf{T}$ & M & $\mathbf{F}$ & $\mathbf{T}$ & Salary & Benefit & Total \\
\hline BMCPFCU & - & - & - & 9 & 2 & 11 & 11 & 2 & 13 & 11 & 3 & 14 & $1,447,437.14$ & -- & $447,437.14$ \\
\hline KFCFCU & 7 & 2 & 9 & 7 & 2 & 9 & 6 & 2 & 8 & 8 & 3 & 11 & 617,976 & $30,998.8$ & $648,974.8$ \\
\hline TCFCU & - & - & - & 5 & 2 & 7 & 6 & 3 & 8 & 7 & 3 & 10 & $872,489.3$ & 22,670 & $895,159.30$ \\
\hline Total & 7 & 2 & 9 & 21 & 6 & 27 & 23 & 7 & 29 & 26 & 9 & 35 & $2,937,902.44$ & $53,668.80$ & 2,991,571.24 \\
\hline
\end{tabular}

Source: Unions Annual Report, 2008 E.C.

Unemployment is one social problem in our country. Therefore Cooperatives are required to create job for citizens in fulfilling the government gap. The table above shows that both three unions expended birr 2,991,571.24 for employee salaries and benefit. But the job creation was not performed by planning to create it but only due to done when there are temporary coffee marketing activity happens and to fill office employees when required.

\subsubsection{Expansion of Community Concerned projects}

In addition to providing objective oriented services to the members Cooperatives are also required by all communities and the government to serve morally and legally too. In this study the researchers are interested to investigate projects that were done in study areas by Cooperatives like expansion of coffee collection units nearest to farmers, forest development, job creation, and building of different infrastructures such as schools, health centers, water supply etc. 
Table 9. Community concerned projects undertaken by cooperative unions

\begin{tabular}{|l|c|c|c|c|c|c|}
\hline \multirow{2}{*}{ Type of Project } & \multicolumn{6}{c|}{ Response } \\
\cline { 2 - 7 } & \multicolumn{2}{|c|}{ Yes } & \multicolumn{2}{c|}{ No } & \multicolumn{2}{c|}{ Total } \\
\cline { 2 - 7 } & Freq. & \% & Freq. & \% & Freq & \% \\
\hline Pure water supply & 41 & 10.5 & 348 & 89.5 & 389 & 100 \\
\hline Construction/maintenance of School & 55 & 14.1 & 334 & 85.9 & 389 & 100 \\
\hline Road construction & 44 & 11.3 & 345 & 88.7 & 389 & 100 \\
\hline Job creation & 212 & 54.5 & 177 & 45.5 & 389 & 100 \\
\hline Forest Development & 338 & 86.9 & 51 & 13.1 & 389 & 100 \\
\hline Agricultural input supply & 230 & 59.1 & 159 & 40.9 & 389 & 100 \\
\hline Expansion of Coffee processing industry & 292 & 75.1 & 97 & 24.9 & 389 & 100 \\
\hline
\end{tabular}

Source: Researchers field survey, 2018.

The performance in each projects displayed above as 41(10.5\%) replied there is pure water supply activity and 348(89.5\%) said no. Regarding school maintenance (construction) $55(14.1 \%)$ yes and $334(85.9 \%)$ said no. $44(11.3 \%)$ said there is road construction whereas $345(88.7 \%)$ said no at all. Regarding job creation $212(54.5 \%)$ replied there is job creation but $177(45.5 \%)$ said no, 338(86.9\%) responded there is forest development activity and $51(13.1 \%)$ no, 230(59.1\%) said the union supply agricultural input whereas $159(40.9 \%)$ said no, 292(75.1\%) said the unions are working on expansion of coffee processing industry and 97(24.9\%) said no.

Table 10. Members perception on CSR practices of cooperatives

\begin{tabular}{|c|c|c|c|}
\hline Description & Response & Frequency & Percent \\
\hline \multirow{6}{*}{$\begin{array}{l}\text { How would you rate the CSR practices of } \\
\text { Cooperative Unions? }\end{array}$} & Excellent & 25 & 6.4 \\
\hline & Very good & 36 & 9.3 \\
\hline & Good & 30 & 7.7 \\
\hline & Poor & 179 & 46.0 \\
\hline & Very poor & 119 & 30.6 \\
\hline & Total & 389 & 100.0 \\
\hline \multirow{6}{*}{$\begin{array}{l}\text { How would you rate the attention given by } \\
\text { Cooperative for the CSR Practices? }\end{array}$} & Excellent & 33 & 8.5 \\
\hline & Very good & 32 & 8.2 \\
\hline & Good & 24 & 6.2 \\
\hline & Poor & 208 & 53.5 \\
\hline & Very poor & 92 & 23.7 \\
\hline & Total & 389 & 100.0 \\
\hline
\end{tabular}

Source: Researchers field survey, 2018.

According to the table 4.8 above the member's perception on CSR practices of cooperative 


\section{Ml Macrothink}

World Journal of Business and Management

ISSN 2377-4622

2019, Vol. 5, No. 1

societies, out of 389 respondents $25(6.4 \%)$ said excellent, 36(9.3\%) said very good, 30(7.7\%) said good, $179(46.0 \%)$ said poor, and $119(30.6 \%)$ said very poor. Members rated the attention given by cooperatives for the CSR practices as 33(8.5\%) responded excellent, 32(8.2\%) very good, 24(6.2\%) good, 208(53.5\%) poor, and 92(23.7\%) said very poor.

Table 11. The aspect in which CSR practices of coffee union most improved

\begin{tabular}{|c|c|c|c|c|}
\hline \multicolumn{2}{|l|}{ Description } & Frequency & Percent & Rank \\
\hline \multirow{4}{*}{$\begin{array}{l}\text { Management Attention to Corporate } \\
\text { Social Responsibility }\end{array}$} & Highly Improved & 298 & 76.6 & $2^{\text {rd }}$ \\
\hline & Improved & 78 & 20.1 & \\
\hline & No need & 13 & 3.3 & \\
\hline & Total & 389 & 100 & \\
\hline \multirow{4}{*}{$\begin{array}{l}\text { Expansion of community concerned } \\
\text { projects of the Union }\end{array}$} & Highly Improved & 315 & 81 & $1^{\text {st }}$ \\
\hline & Improved & 64 & 16.5 & \\
\hline & No need & 10 & 2.6 & \\
\hline & Total & 389 & 100 & \\
\hline \multirow{4}{*}{$\begin{array}{l}\text { Allocation of Community Concerned } \\
\text { Fund }\end{array}$} & Highly Improved & 288 & 74 & $3 \mathrm{rd}$ \\
\hline & Improved & 93 & 23.9 & \\
\hline & No need & 8 & 2.1 & \\
\hline & Total & 389 & 100 & \\
\hline \multirow{4}{*}{$\begin{array}{ll}\text { Community } & \begin{array}{l}\text { involvement in } \\
\text { evaluating CSR } \\
\text { reporting of the }\end{array} \\
\text { Union } & \end{array}$} & Highly Improved & 261 & 67.1 & 4th \\
\hline & Improved & 115 & 29.6 & \\
\hline & No need & 13 & 3.3 & \\
\hline & Total & 389 & 100 & \\
\hline \multirow{4}{*}{$\begin{array}{l}\text { Community involvement in } \\
\text { community based project planning } \\
\text { of the Union }\end{array}$} & Highly Improved & 251 & 64.5 & 5 th \\
\hline & Improved & 125 & 32.1 & \\
\hline & No need & 13 & 3.3 & \\
\hline & Total & 389 & 100 & \\
\hline
\end{tabular}

Source: Researchers field survey, 2018.

The researchers identified the interest of respondents which aspect should most improved in Unions in undertaking CSR practices. Based on this the above table show that management attention given to CSR ranked $2^{\text {rd }}$ by 298 (76.6\%), expansion of community concerned projects of the Union ranked 1 st by $315(81 \%)$, allocation of community concerned fund 3rd rank by $288(74 \%)$, community involvement in evaluating CSR reporting of the Union by $261(67.1 \%)$ in 4th rank, and community involvement in community based project planning of the Union by $251(64.5 \%)$ in 5th level should be improved.

Table 12. Presence of separate social responsibility budget

\begin{tabular}{|c|c|c|}
\hline Response & Frequency & Percent \\
\hline Yes & 148 & 38.05 \\
\hline No & 241 & 61.95 \\
\hline Total & $\mathbf{3 8 9}$ & $\mathbf{1 0 0 . 0 0}$ \\
\hline
\end{tabular}

Source: Researchers field survey, 2018. 
In conventional certain specific book of account like journal, ledger, and so on are maintained systematically together with some statistical books. But in social accounting no such specific books of accounts are maintained. However, under social cost-benefit (Social statement) method accounts can be prepared on some predetermined bases. The CSR accounting requires for business enterprises to have their own separate social responsibility budget. In this study the field survey has shown that out of 389 respondents 148(38.05\%) replied that there is separate budget to undertake CSR practices. whereas $241(61.95 \%)$ replied as there is no separate budget allocated for CSR practices.

To triangulate the response above secondary data especially annual budget and book of accounts of the unions were evaluated. Hence there is no separate budget was allocated during annual general meeting but when it was requested by stakeholders like Government and the community to support developmental activities the unions allocate budget and perform the activities. Additionally when NGOs working community based activities come to work in collaboration with the Cooperatives by signing memorandum of understanding the cooperatives handles the budget from NGOs and perform community based projects. The unions' financial statement as well as book of records were checked to know whether CSR accounting practice has been maintained or not, but no separate book of record or disclosure in financial statement till observed. In order to capitalize the information drawn from questionnaires of respondents, key informants' response and documents of unions such as annual plan, annual performance and financial reports were analyzed. Based on these the following information was summarized as follows:-

In order to identify whether the Cooperatives are working on "concern for community" principle for sustainable community development giving focus in their bylaws' and regulations were inspected in their documents like minutes of annual meetings, BODs meetings, and different reports, the researches didn't observed. Even government officials' especially cooperative promotion office has no clear follow up and understanding on the issue. The comments given from the respondents regarding unions' corporate social responsibility practices are both members and community members should participate actively during need assessment, planning and decision making, the Unions job creating activity should be managed in planned way, Cooperatives have to create awareness on their activity to the community, to increase enrichment in service to farmers by establishing additional primary cooperatives, they should provide training on different development agendas, it has to avail service centers each kebele to address it development projects, sticking not only in marketing it has to expand its business on irrigation and forest development activities, and should work with different stakeholders' who are working in sustainable community development programs.

\section{Summary, Conclusion and Recommendation}

\subsection{Summary}

Corporate social responsibility is a newly emerging discipline which is ethical obligation of business organization out of its primary objective. Even though cooperatives in their ICA principle have put community concerned practices as their obligation, the actual performance 
is still under question. To know the real practice of Cooperatives on CSR the researchers collected data and come with results that is summarized as follows:

\subsubsection{Regarding the Management attention given to CSR Practices}

The Union Management Reporting about CSR activities to the general assembly as a separate agenda based on the concern for community principle is responded as no by 296(76.1\%) out of 389 samples. Participating Community members on CSR Performance evaluation of Cooperatives is also weak as such that 326(83.8\%) out of 389 respondents said no. $205(52.7 \%)$ responded that awareness of Community on the operation undertaken by Unions on CSR activity is limited. The above response is again supported as the CSR practices of Cooperative Unions is poor by $179(46 \%)$ and very poor by $119(30.6 \%)$ out of 389 response. Additionally the attention given by Cooperatives for the CSR Practices based on concern for community principle is poor by $208(53 . \%)$ and very poor by $92(23.7 \%)$ from 389 response.

\subsubsection{Allocation of Community Concerned Fund}

Even though the management attention to participate and aware community in planning and evaluating of CSR practice performed to the community has limitation, the management bodies are working on CSR issues by allocating some budget for CSR practices. According to the information collected in 2008 E.C Bench Maji Coffee union allocated birr 482,500; kafa Coffee union from 2005-2008 E.C allocated birr 4,743,143.04, and Tepi Coffee union allocated birr 117,845 from 2006-2007 E.C for different community development activities. They created job for 26 male and 9 female in total for 36 citizens paying birr 2,991,571.24 for salary and other benefits for both permanent and temporary employees.

\subsubsection{Expansion of Community Concerned Projects}

The Unions were undertaking different community based projects. But there is disparity in geographical coverage and irregularity in budget allocation as well as project undertaking. For instance the information show that only $41(10.5 \%)$ replied there is pure water supply activity and 348(89.5\%) said no, school maintenance (construction) 55(14.1\%) said yes and $334(85.9 \%)$ said no, 44(11.3\%) said there is road construction whereas 345(88.7\%) no at all, regarding to job creation $212(54.5 \%$ ) replied there is job creation but $177(45.5 \%)$ said no job creation, 338(86.9\%) responded there is forest development activity and 51(13.1\%) no, $230(59.1 \%)$ said the union supply agricultural input whereas 159(40.9\%) said no, 292(75.1\%) said the unions are working on expansion of coffee processing industry and 97(24.9\%) said no. Though most of respondents responded that there is no project performing practice, in reality there are some projects performed as mentioned above in provided budget. The problem is that the Cooperative managements were not being participated the community and the members about the practices they are performing.

The CSR accounting requires for business enterprises to have their own separate social responsibility budget which is displayed in social responsibility accounting statement. In this study the field survey has shown that out of 389 respondents $148(38.05 \%)$ replied that there is separate budget to undertake CSR practices. whereas $241(61.95 \%)$ replied as there is no separate budget allocated for CSR practices. To triangulate this response the unions' financial 
statement as well as book of records were checked but no separate book of record or disclosure in the form of social responsibility accounting.

\subsection{Conclusion}

To identify whether cooperatives are working on corporate social responsibility activities towards sustainable development of community, the researchers undertook research on three unions and identified their practices. For justifying practices performed three main measurements such as attention given by Cooperatives management body, allocation of community concerned fund, and undertaking community concerned projects. Based on the information the analysis came with the information that shows cooperatives are practicing CSR activities with its drawbacks. Though there are job creation, supply of agricultural input, and expansion of coffee processing industry for serving both members and non-members, there are limitations by management body to work towards concern for community principle of cooperatives that is principal based obligation of cooperative societies to work for sustainable community development. Such limitations are the awareness creation activity was not done thoroughly, the community members are not participating on performance evaluation of Cooperatives concerning the service rendered to them, member's perceive that there is poor performance of cooperative unions both on CSR practices and the attention given by coffee producer cooperative unions for the CSR practices.

In order to perform sustainable community development, the management attention given should be clearly practiced allocating separated fund. To identify this both primary and secondary data were analyzed and came with the following results. First the allocation of community concerned fund by the unions for community service is limited and inconsistent. Though there is allocation of fund, it has a drawback of regularity of allocation and limitation of community participation during planning, monitoring, and evaluation of fund consumption. Second even though some response shows that there is separate social responsibility budget, the book of accounting records and financial statements of unions didn't show the separate record even in a supplementary attachment (disclosure).

Though the primary objective of Cooperatives is serving their members, they are also required by all communities and the government to serve morally and legally too. Based on this understanding the third variable to evaluate the practice of cooperatives in performing CSR in this study was identification and observation of development projects performed for community development. Projects undertaken by the Forest Coffee Farmers' Cooperative Unions show that it has good practice in some projects, but there is a gap in awareness and information dissemination about practices of projects in between community, members of Cooperatives and the management body including government officials during need identification, planning, budget allocation, implementation, evaluation, and feedback.

\subsection{Recommendation}

Based on the summary and conclusion reached here above, the following recommendations are forwarded:

$>$ Since Cooperative business is working in the community, the cooperative management 
must consider and apply the practice on sustainable community development activities by participating not only members but also the community at all during need assessment, project planning, implementing, and evaluating the projects.

$>$ The cooperatives are not profit oriented business enterprises rather service oriented one. They serve their members in minimum cost without compromising quality and at a time from the activity they earn surplus which is the source for financial increment and patronage dividend to the members. Therefore, from this surplus in their annual general meeting they have to allocate the amount of community concerned budget as a fund for CSR activities.

$>$ As Cooperatives are established by the individuals living in a given geographic area with similar working and living condition for the same objective achievement, whether their business is continuing forever or dismantled the resource is remained to the community according to the cooperative law. Therefore, both GOs and NGOs working on sustainable development activity must work with cooperatives by signing memorandum of understanding.

$>$ Finally, the unions must maintain separate book of account to record financial activities of cooperative social responsibility undertaken by allocated funds and have to report to the community through social responsibility financial statement. This creates mutual understanding among Cooperatives and the community which finally brings ownership sense for all community to the cooperative enterprise.

\section{Acknowledgements}

Thanks to God for all supports to accomplish our research work. We have great respect to our college and Research directorate for financial, moral, and technical support. For unreserved support during data collection period, we have great appreciation to Bench Maji, Kaffa, and Sheka (Yeki woreda) Zone Cooperative promotion office, Coffee unions, Primary cooperative Societies Management bodies.

\section{References}

Adeyemi, B. (2014). Corporate Governance and Cooperative Societies: A Survey of Tertiary Institutions in Oyo, Nigeria. Developing Country Studies, 4(12).

Alessia, D’Amato, Sybil, H., \& Sue, F. (2009). Corporate Social responsibility and sustainable business a guide to leadership tasks and functions. Center for Creative Leadership Greensboro, North Carolina.

Aminul, I., \& Mohammad, A. H. (2014). Analyzing and developing corporate social responsibility practices of kingshuk co-operative society (lst ed.). In Bangladesh, Tornio, Finland.

Asemamaw, T. D. (2011). Corporate Social Responsibility in Sustainable Environment Management in Ethiopia: The case of selected corporations and social enterprises. Addis Ababa University. 


\section{Macrothink}

World Journal of Business and Management

ISSN 2377-4622

2019, Vol. 5, No. 1

Bezabih, E. (2009). Cooperatives: A path to economic and social empowerment in Ethiopia. CoopAFRICA Working Paper no. 9.

Broomhill, R. (2007). Corporate social responsibility, key issues and debates. Dunstan Paper No. $1 / 2007$

Chandra, D. (2010). Corporate governance: PHL Learning Private Limited. New Delhi.

Claudia, T., Ludmila, H., \& Guțu A. (2012). Study on Corporate Social Responsibility of Cooperative Enterprises in the Republic of Moldova. Economy Transdisciplinarity Cognition, $X V(1)$.

Consumer cooperative social responsibility, Bringing values into retail business. Retrieved from http://www.eurocoop.coop 2008

Co-operative Group Sustainability Report. (2013). Retrieved from http://www.cooperative.coop/corporate/Investors

Credit Union Cydney. (2007). Cooperative social responsibility value statement: Newsletter 2007 (Special Edition).

Definitions of corporate social responsibility -What is CSR? (2016). Retrieved from http://mallenbaker.net/accessed

Elizabeth, C., kurucz, B. A., \& Colbert, D. W. (2008). The business case for corporate social responsibility.

Federal Negarit Gazeta of the Federal Democratic Republic of Ethiopia. (1998). Cooperative Societies Proclamation No. 147/1998, p. 942.

Fentaye, K., Hailu, K., \& Rama, M. R. (2016). Perception of Local Community on Corporate Social Responsibility of Brewery Firms in Ethiopia. International Journal of Science and Research (IJSR), 6(14).

Financial Times. (2016). Definition of corporate social responsibility. Retrieved from http://lexicon.ft.com/

International Institute for Labour Studies. (2008). Governance, International Law \& Corporate Social Responsibility. Research Series 116, CH-1211 Geneva (Switzerland).

Joshua, O. M. (2013). Corporate Social Responsibility: Global Idea and National Importance in the 21st Century. IJARMSS, 2(3).

Karthikeyan, M. (2013). Social statement approach to cooperative social performance assessment: A Case of Lume Adama Farmers' Cooperative Union in Ethiopia.

Kimberly, Z. (2002). The Role of Cooperatives in Community Development: "Working together for stronger cooperatives. University of Wisconsin Center for Cooperatives, Bulletin No. 3, 230 Taylor Hall, 427 Lorch St. Madison, WI 53706.

Lyon, T. P., \& Maxwell, J. W. (2008). Corporate Social Responsibility and the Environment: 


\section{Macrothink \\ World Journal of Business and Management \\ ISSN 2377-4622 2019, Vol. 5, No. 1}

A Theoretical Perspective. https://doi.org/10.1093/reep/ren004

Mellan, B. (2015). Ethiopia: Corporate social responsibility.

Rajasekhara, M. P., \& Zelalem, T. (2008). Corporate social responsibility: An attitude of Ethiopian corporates. Social Responsibility Journal, 4(4), 456-46. https://doi.org/10.1108/17471110810909867

Social Responsibility In Cooperatives: A Contribution For Sustainability. (2016). Retrieved from http://www.cdi.coop/icaprinciples.html

\section{Acronyms}

BOD

Board of Directors

BMCPFCU

Bench Maji Coffee Producer Farmers' Cooperative Union

CSR

Corporate Social Responsibility

CSA

Central Statistics Agency

FCPFCU

Forest Coffee Producer Farmers' Cooperative Union

FGD

Focus Group Discussion

GA

General Assembly

ICA

International Cooperative Alliance

$\mathrm{KCPA}$

Kebele Cooperative Promotion Agent

KFCFCU

Kafa Forest Coffee Farmers' Cooperative Union

MFI

Micro-Finance Institution

NGO

Non-Government Organization

PC

Primary Cooperatives

SR

Social Responsibility

SNNPR

South Nations, Nationalities, and Peoples Regional State

TCFCU

Tepi Coffee Farmers' Cooperative Union

US

United States

\section{Copyright Disclaimer}

Copyright for this article is retained by the author(s), with first publication rights granted to the journal.

This is an open-access article distributed under the terms and conditions of the Creative Commons Attribution license (http://creativecommons.org/licenses/by/3.0/). 